\title{
Heavy metals status of the urban and agricultural soils of Peshawar, Pakistan
}

\author{
M.J. Khan ${ }^{1}$, Habib-Ur-Rehman ${ }^{2}$, A.K.K. Achakzai ${ }^{3 *}$, Y. Iqbal ${ }^{2}$, Wali \\ Ullah $^{2}$, Nadir Khan ${ }^{4}$, M. Sharif ${ }^{1}$, M. Afzal ${ }^{1}$, Z.A. Bazai ${ }^{3}$ and F. Ullah ${ }^{1}$ \\ 1Department of Soil and Environmental Sciences, Agriculture University Peshawar, Pakistan. \\ 2Institute of Chemical Sciences University of Peshawar, Pakistan. \\ 3Department of Botany University of Balochistan, Quetta, Pakistan. \\ 4National Center of Excellence in Physical Chemistry, University of Peshawar, Pakistan. \\ *Corresponding Author E-mail: profakk@yahoo.com
}

Citation

M.J. Khan, Habib-Ur-Rehman, A.K.K. Achakzai, Y. Iqbal, Wali Ullah, Nadir Khan, M. Sharif, M. Afzal, Z.A.

Bazai and F. Ullah. Heavy metals status of the urban and agricultural soils of Peshawar, Pakistan. Pure and Applied Biology. Vol. 4, Issue 3, 2015, pp 418-426. http://dx.doi.org/10.19045/bspab.2015.43018

\begin{tabular}{lcc}
\hline \hline Received: 25/07/2015 & Revised: 22/08/2015 & Accepted: 28/08/2015 \\
\hline \hline
\end{tabular}

Soil is a crucial component of urban and rural environments, and in both places land management is the key to soil quality. Unfortunately mining, manufacturing, and the use of synthetic products viz., pesticides, paints, batteries, industrial waste, and land application of industrial or domestic sludge can result in heavy metal contamination of urban and agricultural soils. Heavy metal pollution of soil is a significant environmental problem and has its negative impact on human health and agriculture. Therefore, the present study was mainly conducted to investigate the physico-chemical characteristics and concentrations of heavy metals viz; $\mathrm{Zn}^{2+}, \mathrm{Fe}^{2+}, \mathrm{Cu}^{2+}, \mathrm{Mn}^{2+}$, $\mathrm{Cr}^{2+}, \mathrm{Cd}^{2+}, \mathrm{Ni}^{2+}$, and $\mathrm{Pb}^{2+}$ in the selected soil samples colleted from three depths receiving municipal wastewater of Peshawar City. Results showed that textural class of the soil varied from silt loam to sandy loam with $\mathrm{pH}$ of soil samples ranging from 7.30 to 8.89 with an average value of 8.09 that was slightly alkaline. The EC of the soil samples ranges from 0.2 to $0.9 \mathrm{dS} \mathrm{m}^{-1}$ with an average value of $0.5 \mathrm{dS} \mathrm{m}{ }^{-1}$ showing no salinity problem. The concentrations of $\mathrm{Zn}^{2+}, \mathrm{Fe}^{2+}$, $\mathrm{Cu}^{2+}, \mathrm{Mn}^{2+}, \mathrm{Cr}^{2+}, \mathrm{Cd}^{2+}, \mathrm{Ni}^{2+}$, and $\mathrm{Pb}^{2+}$ ranges from 0.86-3.98, 11.92-31.73, 2.85-6.83, 14.92-19.19, $0.11-0.86,0.04-0.58,0.54-0.96$, and $3.16-38.3 \mathrm{mg} \mathrm{kg}^{-1}$ with an average values of 2.14, 21.44, 5.11, $17.59,0.35,0.28,0.73$ and $17.18 \mathrm{mg} \mathrm{kg}^{-1}$ in surface soils $(0-15 \mathrm{~cm})$, respectively. While it ranges from 0.64-3.37, 11.03-23.91, 2.48-6.83, 10.7-16.33, 0.05-0.23, 0.01-0.35, 0.06-0.64 and 1.44$40.36 \mathrm{mg} \mathrm{kg}-1$ with an average values of $1.78,18.42,4.31,14.03,0.12,0.15,0.42$ and $12.85 \mathrm{mg}$ $\mathrm{kg}^{-1}$ in sub-surface soils (30-45cm), respectively. The concentrations of $\mathrm{Cr}^{2+}, \mathrm{Fe}^{2+}$ and $\mathrm{Ni}^{2+}$ were within safe limits while $\mathrm{Cu}^{2+}$ and $\mathrm{Mn}^{2+}$ concentrations were above the permissible limits of WHO standards. The concentrations of $\mathrm{Zn}^{2+}, \mathrm{Cd}^{2+}$ and $\mathrm{Pb}^{2+}$ in the soil samples collected from the bank of municipal wastewater drain of Peshawar city were above the permissible limits of WHO standards. None of the soil samples showed phytotoxically excessive concentrations of aforementioned heavy metals.

Keywords: Soil; physical; Chemical; Characteristics; Heavy metals; Waste water; City effluents. 


\section{Introduction}

Pollution can be defined as the human alteration of physical or chemical characteristics of the environment to a level that is harmful to living creature. Soil pollution refers to an increased degree of harmful human-made chemicals in the natural soil environment. Soil pollution is becoming a serious problem due to rapid growth of population, urbanization and industrialization. The excessive soil pollution can cause major problem for ecosystem by affecting the lower pyramid levels of the food chain and disrupting its proper functioning. Of the nine major forms (air, light, littering, noise, radioactive, thermal, visual and water), soil pollution is one of the most important one. Soil contamination occurs when chemicals are released by spill or underground leakage. Soil is considered to be the safe heaven and ultimate sink for variety of wastes and pollutants. Among the most significant soil contaminants are hydrocarbons, MTBE, herbicides, pesticides, chlorinated hydrocarbons, paints, batteries, industrial waste, and land application of industrial or domestic sludge can result in heavy metal contamination. Heavy metals also occur naturally, but rarely at toxic levels [1].

Heavy metals are conventionally defined as elements with metallic properties and having an atomic number $>20$. Metals are natural components in soil with a number of heavy metals being required by plants as micronutrients. Regarding the role of heavy metals in living systems, they are divided into two groups i.e. essential and non-essential. Essential heavy metals are those, which are needed by living organisms for their growth, development and physiological functions like $\mathrm{Mn}, \mathrm{Fe}, \mathrm{Ni}, \mathrm{Cu}$ and $\mathrm{Zn}$ [2] while nonessential heavy metals are those, which are not needed by living organisms for any physiological functions like $\mathrm{Cd}, \mathrm{Pb}, \mathrm{Hg}$ and As [3-5]. Higher levels of heavy metals disturb the normal physiology and biochemistry of living systems. The most dangerous heavy metals are $\mathrm{Pb}, \mathrm{Hg}, \mathrm{As}, \mathrm{Cd}$, $\mathrm{Sn}, \mathrm{Cr}$ etc $[6,7]$. Among these, $\mathrm{Cd}$ and $\mathrm{Pb}$ are the most dangerous metals for human health [8].

Heavy metal pollution of soil is a significant environmental problem and has its negative impact on human health and agriculture. The increasing use of wide variety of heavy metals in industries and agriculture has caused a serious concern of environmental pollution $[9,10]$. Heavy metals like $\mathrm{Zn}^{2+}$, $\mathrm{Fe}^{2+}, \mathrm{Cu}^{2+}, \mathrm{Mn}^{2+}, \mathrm{Cr}^{2+}, \mathrm{Cd}^{2+}, \mathrm{Ni}^{2+}$, and $\mathrm{Pb}^{2+}$ are the most hazardous pollutants because of their non-biodegradable nature. These metals find specific adsorption sites in the soil where they are retained relatively stronger either on inorganic or organic colloids. They find their way to food chain disrupting or impairing the natural biotic cycle [11-14]. Excess of heavy metal accumulation in soils is toxic to humans and other animals. Exposure to heavy metals is normally chronic (exposure over a longer period of time), due to food chain transfer [15].

The use of city effluents for irrigation purpose may also result in accumulation of macro $\left(\mathrm{Na}^{+}, \mathrm{K}^{+}, \mathrm{Mg}^{2+}, \mathrm{Ca}^{2+}\right)$ and microessential elements $\left(\mathrm{Fe}^{2+}, \mathrm{Mn}^{2+}, \mathrm{Zn}^{2+}\right)$ as well as trace and toxic elements $\left(\mathrm{Pb}^{2+}, \mathrm{Ni}^{2+}, \mathrm{Cd}^{2+}\right.$, $\mathrm{Cr}^{2+}$, and $\mathrm{Co}^{2+}$ ) in phytotoxic concentrations $[16,17]$, which may adversely affect the human metabolism. Therefore, wastewater application on agricultural lands and their heavy metal accumulation by vegetables is a cause of serious concern due to the potential public health impacts. The sensitivity of plants and animals differs strongly for the deficiency and excess levels of particular metal. It is very difficult to establish a single critical value of deficiency or potential toxicity of particular metal for various species of plants and animals [18]. Soils in vegetable growing areas contain large amounts of $\mathrm{Cd}^{2+}, \mathrm{Pb}^{2+}, \mathrm{Cr}^{2+}, \mathrm{Cu}^{2+}, \mathrm{Zn}^{2+}, \mathrm{Mn}^{2+}$ 
and $\mathrm{Fe}^{2+}$, and there are possibilities of elevated uptake of heavy metals by food crops in Cd-contaminated soils [19]. Longterm application of city effluent may increase the concentration of heavy metals to considerable levels in soil and ultimately in vegetation growing in these soils [20].

Like other developing countries raw wastewater is used in Pakistan for agricultural purposes. Peshawar is the capital city KPK Province of Pakistan. The soils of Peshawar valley are generally alkaline in nature and produce all types of crops and fruits [21]. However, due to poor management practices and pollution of soil particularly by heavy metals, the production is not of satisfactory level. The growing crops especially vegetables and fodders in the vicinity of Peshawar are irrigated with polluted water that affects the soil, plants and animals. To evaluate the potential effects on crops productivity and toxicity to animals and human beings, it is important to determine the concentrations of heavy metals in soil as well as soil physical and chemical properties, which affect the availability of heavy metals. As soil is a crucial component of rural and urban environments, and in both places land management is the key to soil quality [15]. Keeping in view the importance of heavy metals, the present study was therefore mainly designed to determine the $\mathrm{pH}$, electrical conductivity, texture and concentrations of eight species of heavy metals in soil receiving municipal wastewater of Peshawar City.

\section{Materials and Methods \\ Collections and preparation of soil samples}

Soils located in the vicinity around Municipal area of Peshawar receiving wastewater and grown with vegetables \& fodders were collected for their analysis of physicochemical characteristics. Composite soil samples from five diverse locations each comprising of three depths i.e., 0-15, 15-30 and 30-45 cm depth were collected thus a total of fifteen (15) soil samples altogether were taken. Soil Auger was used for sampling. About $1 \mathrm{~kg}$ of sample that was a composite of 10-15 core samples was mixed, labeled and brought to the laboratory of Soil and Environmental Sciences Laboratories of KP Agricultural University Peshawar. The soil samples were then air dried in shade, ground with a wooden mortar and sieved through $2 \mathrm{~mm}$ sieve. The samples were then tightly packed in polythene bags, labeled and stored for further analysis. Each sample was analyzed in triplicate for the desired parameter.

\section{Analysis of soil samples}

The soil samples were analyzed for $\mathrm{pH}$, Electrical conductivity (EC), and texture and AB-DTPA extractable heavy metals. The rational of using AB-DTPA method is that it extracts the soil easily available fraction of metals.

The $\mathrm{pH}$ and EC of the collected soil samples were determined in 1:1 soil and water suspension by using $\mathrm{pH}$ meter model HI 8418 (Hanna) and conductivity meter model pcm 3 (Jenway) respectively at $25{ }^{\circ} \mathrm{C}$ [22]. The texture was determined by Bouyoucos hydrometer method using $\mathrm{Na}_{2} \mathrm{CO}_{3}$ as dispersing or deflocculating agent, as described by [23].

AB-DTPA extractable heavy metals $\left(\mathrm{Zn}^{2+}\right.$, $\mathrm{Fe}^{2+}, \mathrm{Cu}^{2+}, \mathrm{Mn}^{2+}, \mathrm{Cr}^{2+}, \mathrm{Cd}^{2+}, \mathrm{Ni}^{2+}$, and $\mathrm{Pb}^{2+}$ ) in soil samples were determined with the help of atomic absorption spectrophotometer model Perkin-Elmer 2380 USA, by using $\mathrm{NH}_{4} \mathrm{HCO}_{3}$-DTPA extracting solution, as described by [24].

The AB-DTPA $(0.5 \mathrm{M})$ extracting solution was prepared by dissolving $1.97 \mathrm{~g}$ of DTPA in pure water. Two $\mathrm{mL}$ of $1 \mathrm{~N} \mathrm{NH}_{4} \mathrm{OH}$ was added to facilitate dissolution of DTPA and prevent effervescence when bicarbonate $\left(\mathrm{HCO}_{3}\right)$ is added. When most DTPA was dissolved, 79.06 $\mathrm{g} \mathrm{N}_{4} \mathrm{HCO}_{3}$ was added and stirred gently until dissolved. The $\mathrm{pH}$ was 
adjusted (by adding $0.5 \mathrm{~N} \mathrm{HCl}$ ) to 7.6 and the solution was finally made to $2 \mathrm{~L}$ volume. The extracting solution was stored in refrigerator. Twenty mL AB-DTPA extracting solution was added to exactly $10 \mathrm{~g}$ air-dried soil sample and shaken for 30 minutes. After shaking, the suspension was filtered thorough Whatman filter paper No 42. The filtrate was then analyzed for extractable viz., $\mathrm{Zn}^{2+}, \mathrm{Fe}^{2+}$, $\mathrm{Cu}^{2+}, \mathrm{Mn}^{2+}, \mathrm{Cr}^{2+}, \mathrm{Cd}^{2+}, \mathrm{Ni}^{2+}$, and $\mathrm{Pb}^{2+}$ by using atomic absorption spectrophotometer.

\section{Results and Discussion}

\section{Physicochemical characteristics of soil}

The range and average values of $\mathrm{pH}$, electrical conductivity (EC) and texture of soil samples collected from the vicinity of different sites of Peshawar city receiving municipal waste water are shown in Table 1 $\& 2$. The $\mathrm{pH}$ value of surface soils $(0-15 \mathrm{~cm})$ was ranging from 7.30 to 8.43 with an average value of 7.98 . In sub soils $(30-45 \mathrm{~cm})$, it ranges from 7.45 to 8.70 with an average value of 8.16 . The $\mathrm{pH}$ values increased with depth in almost all the soils. The relatively low $\mathrm{pH}$ values in the surface soils could be associated with microbial activities and high organic matter content that upon decomposition produces acidic compounds. The overall $\mathrm{pH}$ of the soils ranges from 7.30 (sample No. A-1) to 8.89 (sample No. E-3), with an average value of 8.09 , indicating that the soil of this area is alkaline and might cause nutritional imbalance for crops grown in this area. Similar observations are also recorded by Liang et al. [31] in China. However, contrary results have been reported by [25], which might be due to sandy textural soil.

The EC (electrical conductivity) values of surface soils $(0-15 \mathrm{~cm})$ ranged from 0.4 to 0.6 $\mathrm{dS} \mathrm{m} \mathrm{m}^{-1}$ with an average value of $0.5 \mathrm{dS} \mathrm{m}^{-1}$. In sub-soils $(30-45 \mathrm{~cm})$, it ranges from $0.2 \mu \mathrm{S}$ to $0.9 \mu \mathrm{S}$ with an average value of $0.5 \mu \mathrm{S}$. The overall EC (when averaged across depth and locations) of the soils ranged from $0.2 \mathrm{dS} \mathrm{m}^{-}$ ${ }^{1}$ (sample No. C-2) to $0.9 \mathrm{dS} \mathrm{m}^{-1}$ (sample No.
A-3) with an average value of $0.5 \mathrm{dS} \mathrm{m} \mathrm{m}^{-1}$ showing that none of the soil is saline and the salinity might not present any problem to agricultural crops. It was further noted that the EC values slightly increased with an increase in depth (except soil sample No. 3) that may be due to leaching of salts from the surface soil. EC is a measure of the salt concentration in the soil solution. Soil electrical conductivity is one of the soil physical properties, which have a good relationship with the other soil characteristics [26]. Research revealed that EC has been shown to increase with increased manure/compost application rates [27, 28]. Shiralipour et al. [29] reviewed the effects of 6 municipal solid waste compost on soil properties and concluded that while municipal solid waste compost could induce salinity damage, the effects were likely to be much less than from sewage sludge applied at the same loading rate. Bevacqua \& Mellano [30] reported municipal compost causing salinity problems that could threaten the production of sensitive crops. However, present results of EC values are contrary to the work presented by this study?

The texture of soils studied varied from siltyloam to sandy-loam. The variation in texture may be due to parent material and the kind of loess deposition that might have taken place at their respective sites. These findings are also in line with results obtained by [31] in Dunhua sewage irrigation areas of China.

\section{Heavy metals status of soils samples}

The ranges and average values of AB-DTPA extractable heavy metals $\mathrm{Zn}^{2+}, \mathrm{Fe}^{2+}, \mathrm{Cu}^{2+}$, $\mathrm{Mn}^{2+}, \mathrm{Cr}^{2+}, \mathrm{Cd}^{2+}, \mathrm{Ni}^{2+}$, and $\mathrm{Pb}^{2+}$ in various soils samples collected from different sites of Peshawar City, receiving municipal wastewater are shown in the Table $3 \& 4$.

The concentrations of $\mathrm{Zn}^{2+}, \mathrm{Cu}^{2+}, \mathrm{Fe}^{2+}, \mathrm{Mn}^{2+}$, $\mathrm{Ni}^{2+}, \mathrm{Cr}^{2+}, \mathrm{Cd}^{2+}$, and $\mathrm{Pb}^{2+}$ ranging from $0.86-$ $3.98,2.85-6.83,11.92-31.73,14.92-19.19$, $0.54-0.96,0.11-0.86,0.04-0.58$ and 3.16$38.30 \mathrm{mg} \mathrm{kg}^{-1}$ with an average values of 2.14 , 
$5.11,21.44,17.59,0.73,0.35,0.28$ and 17.18 $\mathrm{mg} \mathrm{kg}^{-1}$, respectively in surface soils (0$15 \mathrm{~cm})$. In sub-soils $(30-45 \mathrm{~cm})$, the concentrations of $\mathrm{Zn}^{2+}, \mathrm{Cu}^{2+}, \mathrm{Fe}^{2+}, \mathrm{Mn}^{2+}$, $\mathrm{Ni}^{2+}, \mathrm{Cr}^{2+}, \mathrm{Cd}^{2+}$, and $\mathrm{Pb}^{2+}$ ranges from 0.64$3.37,2.48-6.83,11.03-23$.91, 10.7-16.33, $0.06-0.64,0.05-0.23,0.05-0.23,0.01-0.35$ and 4.36-1.44 $\mathrm{mg} \mathrm{kg}^{-1}$ with an average values of $1.78,4.31,18.42,14.03,0.42,0.12,0.15$ and $12.85 \mathrm{mg} \mathrm{kg}^{-1}$, respectively. Results also showed that the concentrations of metals decreased with an increase in soil depth, which might be due to their adsorption on organic matter or due to inputs from municipal wastewater.

By comparing the concentrations of metals of various soils with critical soil test value for crops in soil according to Halvin and Sultanpour [24] showed that all the essential microelements $\left(\mathrm{Zn}^{2+}, \mathrm{Cu}^{2+}, \mathrm{Fe}^{2+}\right.$ and $\left.\mathrm{Mn}^{2+}\right)$ were above the critical value of plant requirement that may cause phytotoxicity. Whereas, according to WHO prescribed permissible limits, it was observed that the concentrations of $\mathrm{Zn}^{2+}, \mathrm{Fe}^{2+}, \mathrm{Cr}^{2+}, \mathrm{Cd}^{2+}$ and $\mathrm{Pb}^{2+}$ were within the WHO permissible limits except soil No. 1 and 2, which had $\mathrm{Zn}^{2+}, \mathrm{Cd}^{2+}$ and $\mathrm{Pb}^{2+}$ concentrations above the set limits. Achakzai et al. [32] demonstrated that the total concentrations of $\mathrm{Cu}^{2+}, \mathrm{Fe}^{2+}, \mathrm{Mn}^{2+}, \mathrm{Zn}^{2+}$ and $\mathrm{Ni}^{2+}$ in lettuce receiving city effluents are within the recommended international standards set by WHO/FAO, but could be reached to toxic level either by the consecutive use of effluents or by increased dietary pattern of the consumers community. As we know that crops grown in polluted soil are taking up excess amount of heavy metals, which ultimately seriously suffer the human health by consuming such crop plants or their parts especially roots [1]. Research studies also revealed that among all heavy metals, $\mathrm{Cd}$ and $\mathrm{Pb}$ are the most dangerous ones for human health [8]. Cd is considered as the most serious pollutant of the modern age [33]. Cd concentrations above the threshold limit values have been found to be carcinogenic, mutagenic and teratogenic for a large number of animal species. Cd has also been implicated as an endocrine disruptor. $\mathrm{Pb}$ has been found to be responsible for quite a number of ailments in humans such as chronic neurological disorders especially in fetus and children. This eventually results in behavioral and attitude changes with progressive retardation [34]. Pb-poisoning in children causes neurological damage leading to reduced intelligence, loss of short-term memory, learning disabilities and coordination problems [35]. Contrary to the WHO standard, in the present study the concentration of $\mathrm{Cr}^{2+}$, $\mathrm{Cd}^{2+}, \mathrm{Ni}^{2+}$ and $\mathrm{Pb}^{2+}$ according to KabataPendias and Pendias [36] were below safe limit indicating that it is not the soluble fraction of the metal rather the total concentration that should be taken in to account while considering the suitability of soil or wastewater for crops. The higher concentrations of heavy metals in soils might be due to irrigation with municipal wastewater containing the respective metals or may be due to aerial dust fall as the soil sampled were adjacent to the heavy traffic road. The crops and plants grown in these soils might accumulate higher concentrations of the respective heavy metals. However, the reported concentrations of the metals are not high enough to cause phytotoxicity but the prolong exposure of soil to wastewater irrigation may cause buildup of metals in soil that may be harmful for human and animals consuming the crops in future.

No correlation was found between the concentrations of heavy metals studied and physico-chemical properties of soils. It might be due to different thermodynamic conditions of soils or some geo-chemical properties and anthropogenic factors might be governing the solubility and mobility of metals in soils [37]. 
Table 1. The $\mathrm{pH}$ and EC of different soils, receiving municipal wastewater of Peshawar city

\begin{tabular}{|c|c|c|c|c|}
\hline Soil & Sample No. & Depth (cm) & pH & $\mathrm{EC}\left(\mathrm{dS} \mathrm{m}^{-1}\right)$ \\
\hline \multirow{4}{*}{ 1. Sardar Ahamd Colony } & A-1 & $0-15$ & 7.30 & 0.5 \\
\hline & A-2 & $15-30$ & 7.45 & 0.8 \\
\hline & A-3 & $30-45$ & 7.72 & 0.9 \\
\hline & Average & -- & 7.49 & 0.73 \\
\hline \multirow{4}{*}{ 2. Ring Road Chowk } & B-1 & $0-15$ & 7.46 & 0.4 \\
\hline & B-2 & $15-30$ & 7.92 & 0.3 \\
\hline & B-3 & $30-45$ & 7.68 & 0.4 \\
\hline & Average & -- & 7.69 & 0.37 \\
\hline \multirow{4}{*}{ 3. Sardar Colony } & C-1 & $0-15$ & 8.30 & 0.6 \\
\hline & $\mathrm{C}-2$ & $15-30$ & 8.47 & 0.2 \\
\hline & $\mathrm{C}-3$ & $30-45$ & 8.21 & 0.2 \\
\hline & Average & -- & 8.33 & 0.33 \\
\hline \multirow{4}{*}{ 4. Ganda-wear End } & D-1 & $0-15$ & 8.12 & 0.5 \\
\hline & D-2 & $15-30$ & 8.47 & 0.3 \\
\hline & D-3 & $30-45$ & 8.13 & 0.6 \\
\hline & Average & -- & 8.34 & 0.47 \\
\hline \multirow{4}{*}{ 5. Budni-Drain (near filter plant) } & E-1 & $0-15$ & 8.43 & 0.5 \\
\hline & E-2 & $15-30$ & 8.70 & 0.6 \\
\hline & E-3 & $30-45$ & 8.89 & 0.4 \\
\hline & Average & -- & 8.67 & 0.50 \\
\hline
\end{tabular}

Table 2. Particle size distribution of different soils, receiving municipal wastewater of Peshawar City

\begin{tabular}{|l|c|c|c|c|c|c|}
\hline Soil Series & $\begin{array}{c}\text { Sample } \\
\text { No }\end{array}$ & $\begin{array}{c}\text { Depth } \\
\text { (cm) }\end{array}$ & \% Sand & \% Silt & \% Clay & $\begin{array}{c}\text { Textural } \\
\text { Class }\end{array}$ \\
\hline 1. Sardar Ahamd & 1 & $0-15$ & 14 & 76 & 10 & Silt-loam \\
Colony & 2 & $15-30$ & 11 & 81 & 8 & $/ /$ \\
& 3 & $30-45$ & 9 & 80 & 11 & $/ /$ \\
\hline 2. Ring Road & 4 & $0-15$ & 8 & 78 & 14 & $/ /$ \\
Chowk & 5 & $15-30$ & 13 & 74 & 13 & $/ /$ \\
& 6 & $30-45$ & 13 & 73 & 14 & $/ /$ \\
\hline 3. Sardar Colony & 7 & $0-15$ & 68 & 26 & 6 & Sand-loam \\
& 8 & $15-30$ & 64 & 27 & 9 & $/ /$ \\
& 9 & $30-45$ & 63 & 29 & 8 & $/ /$ \\
\hline 4. Ganda-Wear & 10 & $0-15$ & 65 & 24 & 11 & $/ /$ \\
End & 11 & $15-30$ & 66 & 19 & 10 & $/ /$ \\
& 12 & $30-45$ & 67 & 19 & 14 & $/ /$ \\
\hline 5. Budni-Drain & 13 & $0-15$ & 19 & 68 & 13 & Silt-loam \\
(near filter plant) & 14 & $15-30$ & 17 & 72 & 9 & $/ /$ \\
& 15 & $30-45$ & 22 & 64 & 14 & $/ /$ \\
\hline
\end{tabular}


Table 3. Heavy metals concentrations $\left(\mathrm{mg} \mathrm{kg}^{-1}\right)$ in different soils, receiving municipal wastewater of Peshawar city

\begin{tabular}{|c|c|c|c|c|c|c|c|c|c|c|}
\hline Soil & $\begin{array}{c}\text { Soil } \\
\text { sample }\end{array}$ & $\begin{array}{c}\text { Depth } \\
(\mathrm{cm})\end{array}$ & $\mathrm{Zn}^{2+}$ & $\mathrm{Cu}^{2+}$ & $\mathrm{Fe}^{2+}$ & $\mathbf{M n}^{2+}$ & $\mathrm{Ni}^{2+}$ & $\mathrm{Cr}^{2+}$ & $\mathrm{Cd}^{2+}$ & $\mathbf{P b}^{2+}$ \\
\hline \multirow{4}{*}{$\begin{array}{l}\text { 1. Sardar Ahmad } \\
\text { Jan Colony }\end{array}$} & A-1 & $0-15$ & 3.98 & 6.26 & 31.73 & 14.92 & 0.54 & 0.32 & 0.58 & 38.30 \\
\hline & A-2 & $15-30$ & 3.46 & 6.75 & 31.00 & 11.30 & 0.08 & 0.21 & 0.40 & 41.16 \\
\hline & A-3 & $30-45$ & 3.37 & 6.83 & $23.9 !$ & 10.70 & 0.06 & 0.05 & 0.35 & 40.36 \\
\hline & Mean & -- & 3.60 & 6.61 & 28.88 & 12.31 & 0.23 & 0.19 & 0.44 & 39.94 \\
\hline \multirow{4}{*}{$\begin{array}{l}\text { 2. Ring Road } \\
\text { Chowk }\end{array}$} & B-1 & $0-15$ & 3.64 & 6.83 & 23.42 & 18.70 & 0.96 & 0.22 & 0.50 & 33.72 \\
\hline & B-2 & $15-30$ & 3.51 & 5.13 & 23.28 & 16.33 & 0.85 & 0.18 & 0.38 & 38.00 \\
\hline & B-3 & $30-45$ & 3.27 & 2.48 & 21.63 & 16.01 & 0.70 & 0.14 & 0.28 & 14.22 \\
\hline & Mean & -- & 3.47 & 4.81 & 22.77 & 17.01 & 0.84 & 0.18 & 0.39 & 28.65 \\
\hline \multirow{4}{*}{ 3. Sardar Colony) } & $\mathrm{C}-1$ & $0-15$ & 0.86 & 6.23 & 11.92 & 19.04 & 0.56 & 0.86 & 0.15 & 6.52 \\
\hline & $\mathrm{C}-2$ & $15-30$ & 0.76 & 5.65 & 11.93 & 15.81 & 0.45 & 0.34 & 0.09 & 6.70 \\
\hline & C-3 & $30-45$ & 0.64 & 4.59 & 11.03 & 15.02 & 0.38 & 0.23 & 0.09 & 5.52 \\
\hline & Mean & -- & 0.75 & 5.49 & 11.63 & 16.62 & 0.46 & 0.48 & 0.11 & 6.25 \\
\hline \multirow{4}{*}{$\begin{array}{l}\text { 4. Ganda-Wear } \\
\text { End }\end{array}$} & D-1 & $0-15$ & 1.02 & 3.38 & 19.81 & 16.13 & 0.64 & 0.22 & 0.04 & 3.16 \\
\hline & D-2 & $15-30$ & 0.89 & 2.75 & 19.71 & 12.45 & 0.50 & 0.14 & 0.03 & 2.66 \\
\hline & D-3 & $30-45$ & 0.67 & 3.54 & 19.03 & 12.09 & 0.30 & 0.12 & 0.01 & 2.70 \\
\hline & Mean & -- & 0.86 & 3.22 & 19.52 & 13.56 & 0.48 & 0.16 & 0.03 & 2.84 \\
\hline \multirow{4}{*}{$\begin{array}{l}\text { 5. Budni-Drain } \\
\text { (Near filter plant) }\end{array}$} & E-1 & $0-15$ & 1.18 & 2.85 & 20.32 & 19.19 & 0.94 & 0.11 & 0.11 & 4.20 \\
\hline & E-2 & $15-30$ & 0.97 & 3.85 & 20.05 & 17.58 & 0.82 & 0.05 & 0.02 & 4.86 \\
\hline & E-3 & $30-45$ & 0.95 & 4.09 & 16.50 & 16.33 & 0.64 & 0.08 & 0.01 & 1.44 \\
\hline & Mean & -- & 1.03 & 3.59 & 18.96 & 17.70 & 0.80 & 0.08 & 0.05 & 3.50 \\
\hline
\end{tabular}

Table 4. Ranges and average concentrations $\left(\mathrm{mg} \mathrm{kg}^{-1}\right)$ of heavy metals in selected soils receiving municipal wastewater of Peshawar city

\begin{tabular}{|c|c|c|c|c|c|c|c|c|}
\hline Soil & $\mathbf{Z n}^{2+}$ & $\mathbf{C u}^{2+}$ & $\mathbf{F e}^{2+}$ & $\mathbf{M n}^{\mathbf{2 +}}$ & $\mathbf{N i}^{2+}$ & $\mathbf{C r}^{2+}$ & $\mathbf{C d}^{2+}$ & $\mathbf{P b}^{\mathbf{2 +}}$ \\
\hline $\begin{array}{c}\text { Top- } \\
\text { soil }\end{array}$ & $0.86-3.98$ & $2.85-6.83$ & $\begin{array}{c}11.92- \\
31.73\end{array}$ & $\begin{array}{c}11.92- \\
31.73\end{array}$ & $0.54-0.96$ & $0.11-0.86$ & $0.04-0.58$ & $3.16-$ \\
\hline $\begin{array}{c}\text { Aver } \\
\text { age }\end{array}$ & 2.14 & 5.11 & 21.44 & 17.59 & 0.73 & 0.35 & 0.28 & 17.18 \\
\hline $\begin{array}{c}\text { Sub- } \\
\text { soil }\end{array}$ & $0.64-3.37$ & $2.48-6.83$ & $11.03-23$ & $10.7-$ & $0.06-0.64$ & $0.05-0.23$ & $0.01-0.35$ & $40.36-$ \\
\hline $\begin{array}{c}\text { Aver } \\
\text { age }\end{array}$ & 1.78 & 4.31 & 18.42 & 14.03 & 0.42 & 0.12 & 0.15 & 12.85 \\
\hline
\end{tabular}




\section{Acknowledgements}

The authors acknowledge the cooperation and the support of the Institute of Chemical Sciences of Peshawar University and KP Agricultural University, Peshawar for providing all the facilities required for the completion of this project.

\section{References}

1. Ali H, Naseer M \& Sajad MA (2012). Phytoremediation of heavy metals by Trifolium alaxandrinum. International Journal of Environmental Sciences 2: 14591469.

2. Gohre V \& Paszkowski U (2006). Contribution of the arbuscular mycorrhizal symbiosis to heavy metal phytoremediation. Planta 223: 1115-1122.

3. Suzuki N \& Sano HKN (2001). Screening of cadmium-responsive genes in Arabidopsis thaliana. Plant Cell Environment 24: 11771188.

4. Bidar G, Garcon G, Pruvot C, Waterlot C, Douay F \& Shirali P (2006). "The phytomanagement of soils highly contaminated by metals: Use of Trifolium repens and Lolium perenne as experimental model", Difpolmine Conference, 12-14 December, Le Corum-Montpellier-France, 16.

5. Peng KJ, Luo CL, Chen YH, Wang GP, Li XD \& Shen ZG (2009). Cadmium and other metal uptake by Lobelia chinensis and Solanum nigrum from contaminated soils. Bulletin of Environmental Contamination and Toxicology 83: 260-264.

6. Wright RT (2007) "Environmental Science: Toward a Sustainable Future". 9Th Ed., Prentice Hall of India, New Delhi.

7. Gosh S (2010). Wetland macrophytes as toxic metal accumulators. International Journal of Environmental Sciences 1: 523528.

8. Sekara A, Poniedzialek M, Ciura J \& Jedrszczyk E (2005). Cadmium and lead accumulation and distribution in the organs of nine crops: Implications for phytoremediation. Polish Journal of Environmental Studies 14: 509-516.

9. Jing, YD, He ZL \& Yang XE (2007). Role of soil rhizobacteria in phytoremediation of heavy metal contaminated soils. J. Zhejiang Univ. Sci., 8: 192-207.

10. Sinhal VK, Srivastava A \& Singh VP (2010). EDTA and citric acid mediated phytoextraction of $\mathrm{Zn}, \mathrm{Cu}, \mathrm{Pb}$ and $\mathrm{Cd}$ through marigold (Tagetes erecta). Journal of Environmental Biology 31: 255-259.

11. McBride MB (1994). Environmental Chemistry of Soils. Oxford University Press, N. Y.

12. McBride MB (1995). Toxic metal accumulation from agricultural use of sludge: Are USEPA regulations protective? Journal of Environmental Quality 24: 5-18.

13. Kelly J, Thornton I \& Simpson PR (1996). Urban Geochemistry: A study of influence of anthropogenic activity on heavy metal content of soils in traditionally industrial and non-industrial areas of Britain. Applied Geochemistry 11: 363-370.

14. Li X, Poon C \& Liu PS (2001). Heavy metal contamination of urban soils and street dust in Hong Kong. Applied Geochemistry 16: 1361-1368.

15. Anonymous, (2000). Soil Quality-Urban Technical Note No. 3: Heavy Metal Soil Contamination. USDA, NRCS, Soil Quality Institute 411 S. Donahue Dr. Auburn, AL 36832 334-844-4741 X-177.

16. Qadir M \& Ghafoor A (1997). Metal ion toxicities in soil and vegetables irrigated with city effluents. Research Project Report. Department of Soil Science University of Agriculture Faisalabad, Pakistan.

17. Shah Z \& Riazullah (2003). Evaluation offarm wastes for heavy metals. Pakistan Journal of Soil Science 22: 42-50.

18. Kabata-Pendias A \& Pendias H (1992). Trace Elements in Soils and Plants, 2nd Ed; CRC Press, Inc. Florida.

19. Singh RS \& Singh RP (1994). Distribution of DTPA-extractable $\mathrm{Cd}, \mathrm{Pb}, \mathrm{Cr}$, 
$\mathrm{Cu}, \mathrm{Zn}, \mathrm{Mn}$ and $\mathrm{Fe}$ in soil profiles contaminated by sewage and industrial effluents. Journal of the Indian Society of Soil Science 42: 466-468.

20. Mussarat M, Bhatti AU \& Khan FU (2007). Concentration of metals in sewage and canal water used for irrigation in Peshawar. Sarhad Journal of Agriculture 23: 335-338.

21. Bhatti AV (1997). Irrigated Soils and Water Management in NWFP, Deptt. of Water Management NWFP Agricultural. University Peshawar Pakistan.

22. Richard LA (1954) Diagnosis and Improvement of Saline and Alkali Soils, U.S.D.A. Hand Book, 60, 302.

23. Kochler FE, Modie CD \& McNeal BL (1984). Laboratory Manual for Soil Fertility, Washington State University Pullmann Washington, USA.

24. Halvin JL \& Sultanpour PN (1981). Evaluation of the NH4HCO3 DTPA soil test for $\mathrm{Fe}$ and $\mathrm{Zn}$. Soil Science Society of American Journal 45: 7075.

25. El-Ashry S, Saber M \& Zaghloul AM (2011). Chemical characterization of sandy soils irrigated with sewage effluent for extended periods from a kinetic perspective. Australian Journal of Basic and Applied Sciences 5: 1-11.

26. Seifi MR, Alimardani R \& Sharifi A (2010). How can soil electrical conductivity measurements control soil pollution? Research Journal of Environmental and Earth Sciences 2: 235-238.

27. Chang C, Sommerfeldt TG \& Entz T (1991). Soil chemistry after eleven annual applications of cattle feedlot manure. Journal of Environmental Quality 20: 475-480.

28. Eghball B (2002). Soil properties as influenced by phosphorus- and nitrogen- based manure and compost applications. Agronomy Journal 94: 128-135.

29. Shiralipour A, McConnell DB \& Smith WH (1992). Physical and chemical properties of soils as affected by municipal solid waste compost application. Biomass and Bioenergy 3: 261-26.

30. Bevacqua RF \& Mellano VJ (1994). Cumulative effects of sludge compost on crop yield and soil properties. Communication in Soil Science and Plant Analysis 24: 395-406.

31. Liang J, Chen C, Song X, Han Y \& Liang $Z$ (2011). Assessment of heavy metal pollution in soil and plants from Dunhua sewage irrigation area. International Journal of Electrochemical Science 6: 5314-5324.

32. Achakzai AKK, Bazai ZA \& Kayani SA (2011). Accumulation of heavy metals by lettuce (Lactuca sativa L.) irrigated with different levels of wastewater of Quetta city. Pakistan Journal of Botany 43: 2953-2960. 33. Singh A, Eapen S \& Fulekar MH (2009). Potential of Medicago sativa for uptake of cadmium from contaminated environment. Romanian Biotechnological Letters 14: 4164-4169.

34. Awofolu OR (2005). A survey of trace metals in vegetation, soil and lower animals along some selected major roads in metropolitan city of Lagos. Environmental Monitoring \&. Assessment 105: 431-447.

35. Padmavathiamma PK \& Li LY (2007). Phytoremediation technology: Hyperaccumulation metals in plants. Water, Air and Soil Pollution 184: 105-126.

36. Kabata-Pendias A \& Pendias H (1985). Trace Elements in Soils and Plants. pp. 315. Boca Raton, CRC Press.

37. Adrian DC (1986). Trace Elements in the Terrestrial Environment, Springer, N. Y. 